\title{
The Role of Organization Culture, Leadership and Training Towards Improving Work Performance Country Civil Worker: Case Study in Financial and Development Supervisory Agency
}

\author{
Muhammad Ramaditya $^{1 *}$, Amirul Wahid Prihantoro ${ }^{2}$ \\ ${ }^{12}$ Sekolah Tinggi Ilmu Ekonomi Indonesia, Rawamangun, Jakarta, 13320
}

\begin{abstract}
A B S T R A C T
The objective of this study is analyzed the impact of organizational culture, training, and leadership on the work performance of civil workers in financial and development supervisory agency. This research uses an associative approach with simple random sampling technique which is measured by SEM using the Smart PLS 3.0 application. The population of this study was 330 civil workers in Financial and Development Supervisory Agency (BPKP). The results of the study shown that the Organizational Culture Variables did not significantly influence work Performance of the civil worker in Financial and Development Supervisory Agency, but do not pass the reliability test. Training Variables have a positive and significant effect on the work performance of the civil workers. Leadership variables have a positive and significant effect on the work performance of the civil workers in Financial and Development Supervisory Agency.
\end{abstract}

A R T I C LE I N F O

\author{
Article History: \\ Received : 01-05-2020 \\ Revised : 22-06-2020 \\ Accepted : 22-06-2020 \\ Published : 30-06-2020
}

\section{Keywords:}

Organizational Culture

Leadership

Trainning

Work Performance

Civil Workers.

*Corresponding Author E-mail:

ramaditya@stei.ac.id

Copyright (@) 2020 Authors. This is an open access article distributed under theCreative Commons Attribution License which permits unrestricted use, distribution, and reproduction in any medium, provided the original work is properly cited.

\section{INTRODUCTION}

One of the objectives of the state and the implementation of the ideals of the nation is carried out by the state civil workers, so that each civil workers needs to have integrity, is professional, cannot be intervened in politics, does not commit corruption, collusion and nepotism, and is able to carry out service functions public based on Pancasila and the 1945 constitution law. In order to be done properly, it is necessary to support the existence of professional, responsible, fair, honest, and competent state civil apparatus human resources.

The main concern of state civil worker is to having basic values, professional ethics, free from political 
intervention, free from corrupt practices, collusion and nepotism. To realize national goals, each state civil apparatus has a duty to carry out certain governmental, public service, and development tasks. the task of the government is carried out in the context of carrying out the general functions of government which include institutional empowerment, staffing, and management. public service duties are carried out by providing services on goods, services, and administrative services provided. Whereas in the context of carrying out certain development tasks carried out through nation building as well as through economic and social development that aimed to improve the welfare and prosperity of the whole community.

The Financial and Development Supervisory Agency (BPKP) is having the vital roles to create good governance to prevent and participate in eradicating corruption in carrying out certain construction tasks. BPKP's mission is to be the world class Indonesian internal auditor to increase accountability in financial management and national development, so that all employees in the BPKP environment are expected to have work performance that implements BPKP values, namely Professional, Integrity, User Orientation, Conscience and Common Sense, Independent, and Responsible. Some factors that can improve employee performance in the BPKP environment include Organizational Culture, Training, and Leadership.

Organizational culture is a shared value system in an organization that determines the level of how employees carry out activities to achieve organizational goals (Sutrisno, 2010). Furthermore, it also defines as a value that guides human resources to deal with external problems and efforts to adjust integration in the organization, so that each member of the organization must be able to understand the values that exist and how they should act and behavior. Organizational culture refers to a system of meaning sharing done by members of the organization that distinguishes the organization from other organizations (Robbins and Judge,
2012).

Organizational culture is a shared value system in an organization that is a reference for how employees carry out activities to achieve the goals or ideals of the organization. organizational culture within the institution and local government can be recognized as an organizational excellence in responding to the challenges and changes that are realized in the form of work culture. The Financial and Development Supervisory Agency has noble values which are also used as guidelines in carrying out Organizational Culture, namely PIONIR. In a narrow sense, PIONIR has a meaning as an initiator, while in a broader meaning, PIONIR is a formation of six values, namely professional, integrity, service orientation, Conscience and common sense, Independent, and Responsible. The organizational culture values possessed by BPKP can be defined as follows:

1. Professional is an attitude and action that prioritizes service quality based on harmonized knowledge, skills and ethics.

2. Integrity is quality, character, or condition that shows unity in words and complete actions so that they have the potential and ability to radiate authority, honesty, consistency and unwavering determination in upholding noble values.

3. Orientation to Users is the desire to help or serve other parties by knowing and meeting the needs of users both internal and external.

4. Conscience and Common Sense is a personality that is able to control emotions, assess the strengths or weaknesses of oneself, be independent, have good interpersonal relationships, and be goal-oriented.

5. Independent. An action and attitude in carrying out the work to not be influenced by anyone and take sides with anyone.

6. Responsibility. responsible for every action and task, both in terms of process and results.

Besides culture, another way to improve is by given a good training. According to Dessler (2015), training means giving new employees or old 
employees the skills they need to do their job. Training is also the process of an employee to reach a certain target criterion where those criteria have been determined by the company and will be used to achieve the company's main objectives. Based on the Regulation of the Republic of Indonesia, every civil worker has the same right and opportunity to participate in Competency Development by taking into account the results of work performance appraisal and competency assessment of the relevant civil workers. The right and opportunity to participate in Competency Development at least 20 hours of training in a year. The development of civil workers competencies can be done through the Education and Training Track. Development of competencies in the form of training is done classically and non-classical. Classical training is carried out through face-toface learning in the classroom at least through training, seminars, courses, upgrading, and professional certification training. Non-classical training at least includes e-learning, guidance in the workplace, distance training, internships, and exchanges between employees.

In order to meet the competency development needs for all employees of BPKP, one of the activities organized by the Financial and Development Supervisory Agency is in the form of Substance Technical Training. Substantial Technical Training is carried out for 5 working days at the BPKP Ciawi Education and Training Center, Bogor. In order to know the effect of training on employee performance, it is necessary to monitor the implementation of Substance Technical Training which is followed by civil workers within the Financial and Development Supervisory Agency. Based on observations, periodic monitoring has not been carried out by the relevant work units. The evaluation that has been carried out is only limited to the evaluation of the training implementation. This training is linked to a result for their performance. Good work performance will increase the efficiency and effectiveness of the organization in managing existing resources in order to achieve the goals set. Performance is shown by comparing the ratio of input to output (Rahmayanti, 2014). On the other hand, leadership also has a significant role in determining the direction and policies of the organization and team. The lowest level leader in the Financial and Development Supervisory Agency is the head of the audit team. According to Robins and Judge (2015) leadership is the ability to influence a group to achieve the vision or goals that have been set. Each leader will show his leadership style through his words, attitudes and behavior that will be felt by himself and others. Leadership style is a characteristic of every leader, it will be different from one leader to another leader. Besides, study in corporate social responsibility and leadership can hardly be separated. Leader with supported with ethical CSR is now an instrument for increased employee engagement in company which cannot be separated from the competitive perspective (Ramaditya, 2019a). However, by having ethical CSR on its leader mindset and programs, company will create greater engagement for their employees (Ramaditya, 2019a). One's leadership can be assessed by observing and noting the qualities and qualities of the behavior. Organizations need leaders who have vision, serve, credible, reliable and trustworthy, have clear values as the basis of every action and decision. Values are communicated through words and actions, so that they can be seen and understood clearly by the team and values become the standard for shared behavior. Effective leadership is the leader who can collaborate, harmonize, build trust, good relationships, align the team members self-confidence and engage the team (Ramaditya, 2019b).

Based on observations, the teams formed in each work unit in the BPKP often change based on the needs and the time period of the assignment. The qualities and qualities of leadership carried out by the team leader within the Financial and Development Supervisory Agency lead to varied team work performance. For team members who are easy to adapt to the qualities and qualities or qualities of the leadership of the designated team leader, team performance can be maximized and can complete the tasks. by its team members, the performance will not be as expected, for example 
the audit report exceeds the specified deadline and the quality of the audit becomes substandard.

Study on employee on BPKP by Ramaditya \& Nazzario (2020) found that that organizational culture, communication, and religiosity positive effect is not significant on work motivation and employee engagement. Hence. work motivation is not proven to mediate cultural, communication and religiosity relationships towards employee engagement (Ramaditya \& Nazzario, 2020). Based on the problem statement proposed in this research, it can be concluded that the objectives of this study are; (1) To analyze the impact of Organizational Culture on civil workers Performance in the Financial and Development Supervisory Agency; (2) to analyze the impact of the Training on civil workers performance in the Financial and Development Supervisory Agency; (4) to analyze the impact of leadership on civil workers performance in the Financial and Development Supervisory Agency.

\section{LITERATURE REVIEW}

\section{Organization Culture}

Culture is a set of meanings and shared values that determine the general way of life and are considered to be many cultures as much as the sum of meanings and values (Hofstede \& Minkov, 2010). Culture is an attitude, norms, values, and ways of thinking that are learned by humans as long and not passed down from one generation to another (Browaeys, 2011). Organizational culture is a value that is owned by an organization that is felt and understood by all members of the organization (Hutapea and Thoha, 2008).Based on some of the theories, it can be concluded that organizational culture is the values and norms owned by the organization to be believed and implemented jointly by members of the organization in achieving organizational goals. Organizational culture created by the founder of a company or organization is formed through a long process (Atoshoki, 2005). There are three stages in forming a company's organizational culture, such as:

1. Creating an organizational culture based on background, basic assumptions, values, beliefs, and ideologies shared by the founder of the organization.

2. Recruitment and selection of members of the organization in accordance with individual values and beliefs held by the founder of the organization.

3. Determine the general climate of behavior that is acceptable and not by all members involved in the organization by top management.

Every organization or company has a culture, but not all organizations have a culture that is equally strong in influencing the behavior and actions of their employees (Robbins and Judge, 2012). An organizational culture can have a level that is a strong organizational culture and weak organizational culture. A strong culture is described as a culture that implements the organization's core values in a strong and widely accepted way among employees, has a greater influence than a weak culture, whereas a weak organizational culture (weak culture) as a culture level where everyone has different values, there are unclear goals and principles that underlie every company decision. According to Robbins (2012), the function of organizational culture is:

1. As a differentiator between the organization and other similar organizations.

2. as an identity for members of the organization.

3. Grow and increase the commitment of members of the organization.

4. As a means of unifying the organization and forming the attitudes and behavior of employees.

5. As a guide to employee attitudes and behavior.

\section{Training}

Training is an environmental container for employees, where they acquire or learn attitudes, abilities, expertise, knowledge, and specific behaviors related to work (Rachmawati, 2008). Training also the process of systematically changing employee behavior to achieve organizational goals (Rivai and Sagala, 2011). Training deals with the expertise and ability of employees to carry out current work. According 
to Eko Widodo (2015), training is a series of individual activities in systematically increasing expertise and knowledge so as to be able to have professional work performance in their fields. Training is a learning process that allows employees to carry out work that is now in accordance with standards. It can be concluded that training is a series of activities aimed at developing and improving skills, work competencies, work productivity, performance, and attitudes to be able to adapt and develop competencies according to their position and type of work.

Training is not only specifically for employees who are just starting to work, but can be as a reward for employees who achieve the best performance and as an increase in competence for employees who have work performance below the specified standards. According to Sutrisno (2009), the training objectives are as follows:

1. Improve accuracy in human resource planning.

2. Supporting personal growth.

3. Improving the quality of work.

4. Maintain health and safety.

5. Improve work morale

6. Increase work productivity.

Every education and training that will be held must always pay attention to the extent to which the pattern of education and training that is organized can guarantee an effective learning process. According to Eko Widodo (2015), the types of training commonly carried out in organizations include on the job training, apprenticeships, off the job training, training in a real similar place (vestibule training) and job simulation.

\section{Leadership}

According to leadership is every effort of someone who tries to influence the behavior of a person or group, efforts to influence this behavior aim to achieve individual goals, goals of friends, or together with organizational goals that may be the same or different (Sunyoto, 2013). Leadership also as a science that comprehensively studies how to direct, influence, and supervise others to carry out tasks according to the planned instructions (Fahmi, 2014).

Leadership is an effort made by every leader to be able to realize individual and organizational goals. According to Wijono Sutarto (2018), there are four main variables of leadership, such as:

1. Characteristics of Leaders. Leader characteristics are the personal characteristics possessed by a leader in leading, directing, assisting, encouraging, and protecting its members in the organization.

2. Attitudes, needs, and personal characteristics of the followers. The success of a leader in leading a group or organization is inseparable from the attitudes, needs, and personal characteristics of his followers. When the leader and his followers are responsible, disciplined, have high commitment, it will support the success of the leader.

3. The organization itself, such as the objectives, structure, and tasks that it carries out the organization should have goals, structure, and tasks that will be formulated by the leader in carrying out the main tasks and functions. The task is used as a guide in carrying out the duties of leaders and followers.

4. Social, economic and political environment. The social, economic, and political environment has influence in leaders to make policies. At a time when the social, economic, and political environment is conducive, leaders can set organizational goals as expected. Conversely, if it is less conducive, the leader will strive to achieve ideal conditions first before increasing performance or expanding organizational goals.

\section{Work Performance}

Work performance is the result of work achieved by someone based on job requirements Bangun (2012). According to Mangkunegara (2013), the factors that influence the achievement of performance are ability factor as psychologically, employees' abilities consist of potential abilities 
and reality abilities and motivation factors is formed from the attitude of an employee in dealing with work situations. Work performance is basically what employees do and don't do (Mathis and Jackson, 2009). The work performance indicators in this study are as follows:

1. Quantity of work provided

2. The quality of the work

3. Timeliness, in completing tasks

4. Presence

5. The ability to cooperate

Based on above described literature the following hypotheses were proposed for this study as follows:

The model in Figure 1. is a conceptual model proposed in this study. The model illustrates the effects of organizational culture, training and leadership on work performance in government agencies. Numerous studies about organizational culture is formed to be able to shape and control the behavior of organizations and organizational members. Organizational culture that is in accordance with the beliefs and behavior of employees will be able to improve the performance of individuals and organizations and if the culture of the existing organization is not in accordance with changes in the environment and the behavior of employees, it will hamper the performance of employees and organizations. In a broader context, organizational culture is related to aspects of individual behavior within the organization. The result of research by Dewi (2014) entitled Analysis of the Effect of Leadership and organizational culture on work performance with a reward system as a moderating variable with the results of the study there is a positive and simultaneous influence of leadership and organizational culture on the performance of the employees.

H1: Organization Culture have positively Influence towards work performance.

Training is one way to improve employee performance. The training is expected to help employees improve their knowledge, skills and performance. So hopefully there is no competency gap between employees. The influence of training on performance was stated by Hasibuan (2010) that employee development through training is to improve the technical, theoretical, conceptual, and moral abilities of employees so that they perform well and achieve optimal results. The research is supported by another study that found training results, work discipline, and motivation to influence employee performance (Eka, 2018).

H2: Training have positively influence towards work performance.

Leadership provides a positive and significant impact on employee performance. The quality of a leader is not determined by the size of the results achieved, but is determined by the ability of leaders. Achieve these results through the mediation of others, namely through his subordinates, as well as the influence emitted by the leader on his subordinates. Leaders must be able to move their subordinates to them. work with enthusiasm to achieve good performance. Enhancement. employee performance can be. Leader. must be able to resolve the problems that occur in the organization and be fair to employees,

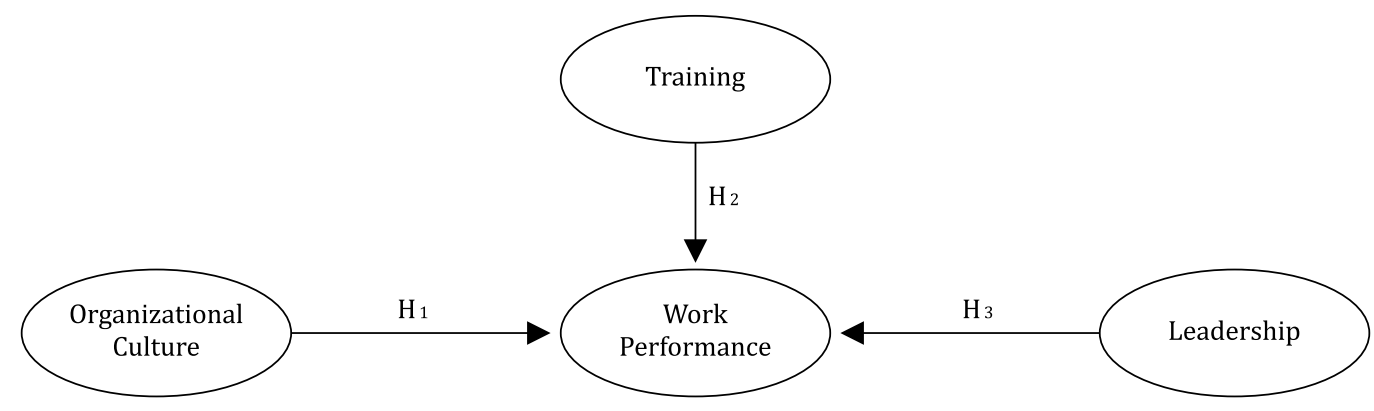

Figure 1. Conceptual Model 
so that the performance in the company will improve. This research was supported by another study found factors that influence on Employee Performance in the Regional Office of the Directorate General State Maluku. results obtained leadership, motivation and work environment have a positive and significant impact on performance (Potu et al., 2013).

H3: Leadership have positively influence towards work performance.

\section{RESEARCH METHOD}

According to Sugiyono (2015), the research method is defined as a scientific way to obtain data with specific purposes and uses. The data obtained through the study is empirical data (observed) which has certain criteria, namely valid. Valid shows the degree of accuracy between the data that actually occurs on the object with data collected by researchers. To get data that is directly valid in research is often difficult, therefore data that has been collected before its validity is known can be tested through reliability and objectivity testing. Generally, if the data is reliable and objective, there is a tendency for the data to be valid. Valid data must be reliable and objective. Reliability regarding the degree of consistency of the data in a certain time interval. Objectivity with regard to interpersonal agreement.

The research strategy used in this study based on the form of problem formulation is associative problem formulation. The formulation of associative problems is the formulation of research problems that are asking the relationship between two or more variables (Sugiyono, 2015). The form of the relationship used in this study is a causal relationship. In this study the independent variables (variables that affect) and dependent variables (variables that are affected). In this study, researchers wanted to know the relationship of Organizational Culture (X1), Training (X2), and Leadership (X3). The purpose of using an associative strategy is to be able to provide an explanation of the relationship of organizational culture, training, and leadership to the work performance of the state civil workers in the financial and development supervisory agency.

Population is a generalization area that consists of objects or subjects that have certain qualities and characteristics that are determined by research to be studied and then conclusions drawn (Sugiyono, 2015). The population is not only people, but also objects and other natural objects. Population is also not just the amount that exists on the object or subject studied, but includes all the characteristics and properties possessed by the subject or object. The population in this study is the State Civil Apparatus at the Central BPKP (Jakarta) which is a total of 1,695 employees.

The sampling technique used by researchers in this study is to use probability sampling with a simple random sampling technique. According to Sugiyono (2015), simple random sampling is a technique of taking sample members from a population carried out randomly without regard to strata that exist in that population. The method is carried out if a member of the population is considered homogeneous. Researchers used probability sampling techniques with simple random sampling techniques because in this study the number of populations was known and each element or member of the population had the opportunity to be chosen. Exceptions are only for State Civil Apparatuses who have less than 5 years of work and who have never been team leaders. Thus, the sample of this study was 330 State Civil Apparatus within the Central Financial and Development Supervisory Agency with an error rate of $5 \%$. The data collected, was analyzed using SEM-PLS (Structural Equation ModelingPartial Least Square) technique in Smart PLS 3.0 software program.

\section{RESULT AND DISCUSSION} Validity and Reliability

Based on gender, respondents in this study were dominated by men, amounting to 230 people or $70 \%$, while female respondents were 100 people or $30 \%$. This shows that the majority of the State 
Civil Apparatus in the Financial and Development Supervisory Agency is male. This is due to the main function of the Financial and Development Supervisory Agency as Internal Government Auditors who are more active in the field to conduct audits on Government Agencies throughout Indonesia. According to Ghozali and Lathan (2015) convergent validity is related to the principle that the gauges of a construct should be highly correlated. The convergent validity test of the reflection indicator with the SmartPLS 3.0 program can be seen from the loading factor value for each construct indicator. Loading factor is a coefficient that explains the level of relationship of indicators with latent variables. In general, the higher the loading factor the better the loading, and values below 0.30 are not interpreted. The rule of thumb used to assess convergent validity is that the loading factor value must be greater than 0.7 and the average variance extracted (AVE) value must be greater than 0.5 . The convergent validity of the measurement model with reflexive indicators can be seen from the correlation between item or indicator scores and construct scores.

Table 1. Average Variance Extracted (AVE) Value

\begin{tabular}{cc}
\hline Item & Average Variance Extracted (AVE) \\
\hline Organization Culture & 0,524 \\
\hline Training & 0,558 \\
\hline Leadership & 0,562 \\
\hline Work Performance & 0,557 \\
\hline
\end{tabular}

Individual indicators are considered reliable if they have correlations above 0.70 but in the development stage the loading scale from 0.50 to 0.60 is still acceptable and the AVE value (Average Variance Extracted) is greater than 0.5.

Tabel 2. Outer Loading

\begin{tabular}{ccc}
\hline $\begin{array}{c}\text { Correlation } \\
\text { Indicator with } \\
\text { Variable }\end{array}$ & Loading Factor & Information \\
\hline $\mathrm{X} 1.1$ & 0,836 & valid \\
\hline $\mathrm{X} 1.2$ & 0,700 & valid \\
\hline $\mathrm{X} 1.3$ & 0,736 & valid \\
\hline $\mathrm{X} 1.4$ & 0,685 & valid \\
\hline $\mathrm{X} 1.5$ & 0,704 & valid \\
\hline $\mathrm{X} 1.6$ & 0,670 & valid \\
\hline $\mathrm{X} 2.1$ & 0,579 & valid \\
\hline
\end{tabular}

\begin{tabular}{|c|c|c|}
\hline $\mathrm{X} 2.2$ & 0,719 & valid \\
\hline $\mathrm{X} 2.3$ & 0,611 & valid \\
\hline X2.4 & 0,659 & valid \\
\hline $\mathrm{X} 2.5$ & 0,690 & valid \\
\hline $\mathrm{X} 2.6$ & 0,829 & valid \\
\hline $\mathrm{X} 2.7$ & 0,895 & valid \\
\hline $\mathrm{X} 2.8$ & 0,826 & valid \\
\hline X2.9 & 0,843 & valid \\
\hline X3.1 & 0,699 & valid \\
\hline X3.2 & 0,838 & valid \\
\hline X3.3 & 0,765 & valid \\
\hline X3.4 & 0,832 & valid \\
\hline X3.5 & 0,766 & valid \\
\hline X3.6 & 0,811 & valid \\
\hline X3.7 & 0,836 & valid \\
\hline X3.8 & 0,811 & valid \\
\hline X3.9 & 0,840 & valid \\
\hline $\mathrm{X} 3.10$ & 0,576 & valid \\
\hline $\mathrm{X} 3.11$ & 0,600 & valid \\
\hline X3.12 & 0,667 & valid \\
\hline X3.13 & 0,625 & valid \\
\hline Y.1 & 0,908 & valid \\
\hline Y.2 & 0,871 & valid \\
\hline Y.3 & 0,908 & valid \\
\hline Y.4 & 0,917 & valid \\
\hline Y.5 & 0,588 & valid \\
\hline Y.6 & 0,840 & valid \\
\hline Y.7 & 0,734 & valid \\
\hline Y.8 & 0,589 & valid \\
\hline Y.9 & 0,641 & valid \\
\hline Y.10 & 0,882 & valid \\
\hline Y.11 & 0,568 & valid \\
\hline Y.12 & 0,532 & valid \\
\hline Y.13 & 0,509 & valid \\
\hline
\end{tabular}

Based on table 1, it showed that the AVE value of each variable is more than 0.5 and based on table 2 the outer loading value of each indicator of each variable is declared valid because it has a value of more than 0.5 which means the overall convergent validity has been fulfilled. Discriminant validity is a reflexive indicator that can be seen cross loading and its construct or by comparing the square root of the AVE (Average Variance Extracted) for each construct of correlation between constructs and other constructs in the model. Discriminant validity if AVE of constructs 
is greater than the correlation between constructs with other constructs that is $>0.5$ in one variable. From table 3 , it showed that the discriminant validity value of the Organizational Culture construct is 0.724 , then the Training construct is 0.747 , then the Leadership construct is 0.750 , and the Performance construct is 0.746 . Based on these results, testing of discriminant validity as a whole has been fulfilled because all constructs have discriminant validity values of more than 0.5 .

According to Ghozali and Latan (2015) to conduct construct reliability testing in SmartPLS 3.0 can be measured using two methods, namely cronbach alpha and composite reliability of the indicator block that measures the construct. The construct is declared reliable if the value of Cronbach alpha and composite reliability is more than 0.7 .

Tabel 4. Cronbach Alpha dan Composite Reliability

\begin{tabular}{lcc}
\hline Item & $\begin{array}{c}\text { Cronbach } \\
\text { Alpha }\end{array}$ & $\begin{array}{c}\text { Composite } \\
\text { Reliability }\end{array}$ \\
\hline Budaya Organisasi & 0,869 & 0,868 \\
\hline Training & 0,917 & 0,917 \\
\hline Leadership & 0,943 & 0,943 \\
\hline Work Performance & 0,941 & 0,940 \\
\hline
\end{tabular}

Source: Ramaditya, 2019

Based on table 4, the reliability testing in this study shows that the measurement variables used in this study can be declared reliable, because it shows Cronbach alpha and composite reliability $\geq 0.7$.

\section{Evaluation of Structural Model (Inner Model)}

Based on Figure 2, the path coefficient values of each independent variable are as follows:The value of the path coefficient of organizational culture on performance is 0.002 . This means that Organizational Culture has a positive effect on the performance of the State Civil Apparatus in the Financial and Development Supervisory
Agency. The value of the training coefficient on performance is 0.577 , this means that the training has a positive effect on the performance of the State Civil Apparatus in the Financial and Development Supervisory Agency. Leadership path coefficient value on Performance of 0.213 , this means that the leadership has a positive effect on the performance of the state civil apparatus in the financial and development supervisory agency.

Hypothesis testing is done by looking at the probability value and t-statistics. For probability values, the P-value with an alpha of $5 \%$ is $<0.05$. The t-table value for alpha $5 \%$ is 1.96 . So the hypothesis acceptance criteria is when t-statistics> t-table. The results of data processing can be seen in Figure 2.

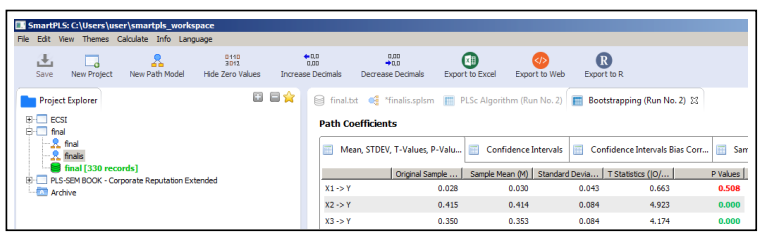

Figure 2. Output Testing Direct Effect

Based on Figure 1, the Organizational Culture variable has a regression coefficient of 0.002 . This shows that there is a positive influence with $t$ statistic which shows a significant effect that is $0.666>0.05$ and $P$ value $0.506>0$. So it can shown that the variable Organizational Culture has a positive and significant effect on the Performance of the State Civil Apparatus in the Financial and Development Supervisory Agency. This shows that the Organizational Culture values can support the improvement of the Performance of the State Civil Apparatus in the Financial and Development Supervisory Agency.

Based on Figure 1, the Training variable has

Tabel 3. Discriminant Validity

\begin{tabular}{ccccc}
\hline Item & Organization Culture & Training & Leadership & Work Performance \\
\hline Organization Culture & $0,724^{*}$ & & & \\
\hline Training & 0,654 & $0,747^{*}$ & & \\
\hline Leadership & 0,712 & 0,961 & $0,750^{*}$ & $0,746^{*}$ \\
\hline Work Performance & 0,539 & 0,790 & 0,776 & \\
\hline
\end{tabular}

Source: Ramaditya, 2019 


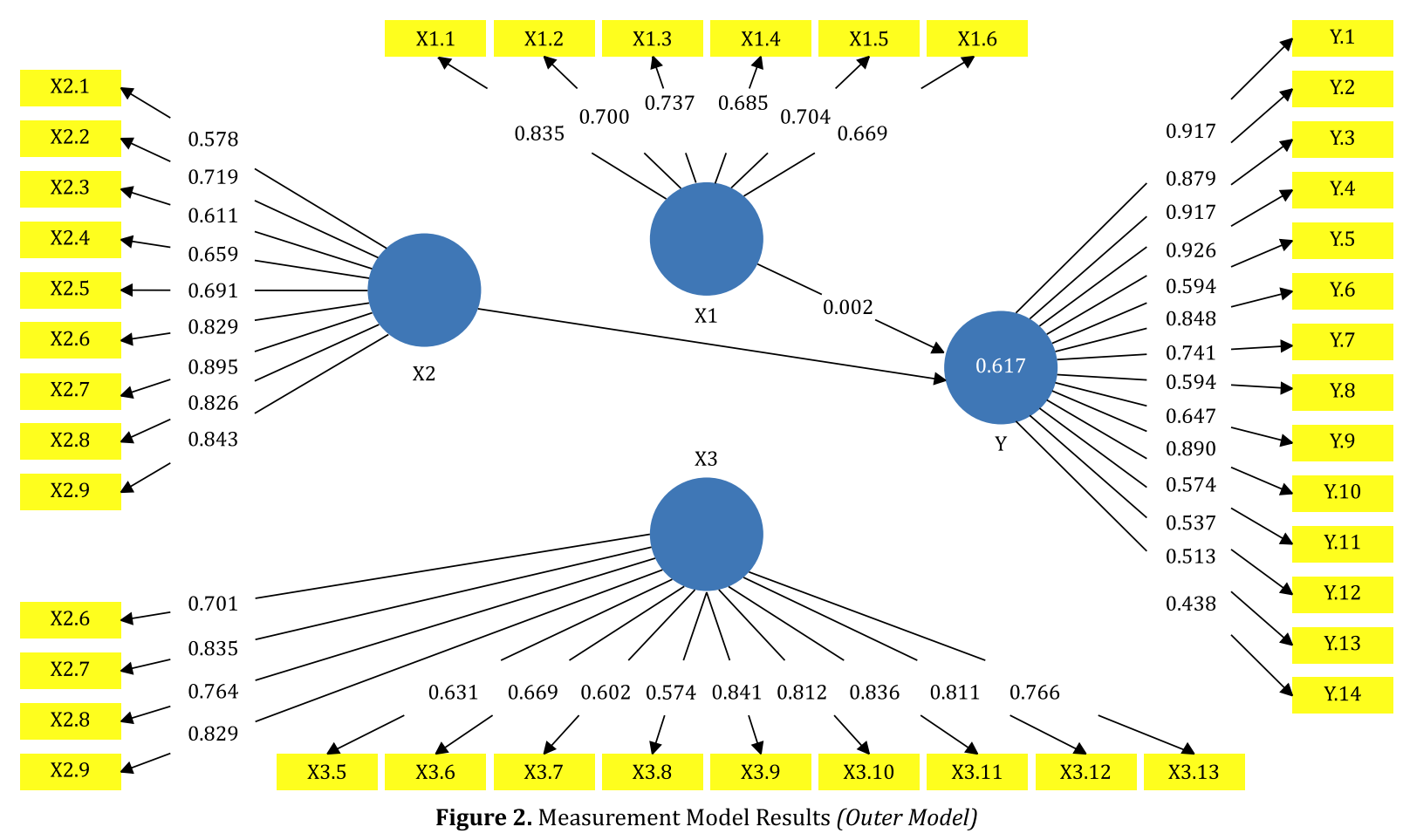

a regression coefficient of 0.577 . This shows that there is a positive influence with the t-statistic which shows a significant effect that is $4,860>$ 0.05 and $P$ value $0=0$. So it can be seen that the training variable has a positive and significant effect on the performance of the State Civil Apparatus in the Financial and Development Supervisory Agency . This shows that the training organized by the Financial and Development Supervisory Agency supports the improvement of the Performance of the State Civil Apparatus in the Financial and Development Supervisory Agency.

Based on Figure 1, the Leadership variable has a regression coefficient of 0.213 . This shows that there is a positive influence with t-statistic which shows a significant effect that is $4.126>0.05$ and the value of $P$ value $0=0$. So it can be seen that the Leadership variable has a positive and significant effect on the Performance of the State Civil Apparatus in the Financial and Development Supervisory Agency. This shows that the leadership characteristics in the Financial and Development Supervisory Agency affect the improvement of the Performance of the State Civil Apparatus in the Financial and Development Supervisory Agency.
By age, the majority of respondents in this study were 29 years and 28 years old, while the respondents were at least 35 years and 26 years old. This shows that the employee who was given the task as the Team Leader already has the maturity in making decisions. For employees who are still too young not too much given trust, while for employees who are already senior the majority have served as supervisors / technical controllers and structural officials.

Based on the length of work, most respondents in this study have worked in the Financial and Development Supervisory Agency for 8 to 9 years. This shows that the longer employees work at the Financial and Development Supervisory Agency, the more experience and skills they have so that it will produce optimal performance

\section{CONCLUSION}

Based on the research results described in the previous chapter, the following conclusions can be drawn that Organizational Culture has a positive and significant effect on Apparatus Performance State Civil in Financial and Development Supervisory Agency. Besides, training has a positive and significant effect on the Performance of the State Civil Apparatus at the Financial and 
Development Supervisory Agency. And leadership has a positive and significant effect on the Performance of the State Civil Workers in Financial and Development Supervisory Agency.

According to this result, the socialization of Organizational Culture in the Financial and Development Supervisory Agency needs to be improved so that it is better understood by every employee in improving their work performance, both in the form of socialization and workshops related to the implementation of Organizational Culture in the Financial and Development Supervisory Agency.

Furthermore, the training variable has a positive and significant effect. According to researchers, the training that has been held needs to be increased in number and periodically evaluated so that all employees can benefit from existing training to support the work performance of all employees, both in the form of rewards for those whose work performance is already good, as well as improving skills for employees who need to improve their work performance.

Finally, the leadership variable has a positive and significant effect. According to researchers, to improve work performance and facilitate the understanding of team members in anticipating differences in team leader leadership types, teams are arranged for assignments within a certain period (semester or yearly).

This study presents opportunities for further research. First, additional research is indicated as to whether other factor such as organizational agility and knowledge management may be a limiting factor in achieving work performance. Second, the case subject was a government agency in Indonesia. Future research should compare the results from surveying similarly sized government agency from different regions in the world such as Malaysia and differently sized institutions. Finally, more research could be undertaken to compare the results of different organizational roles within government agency.

\section{REFEREN CES}

Atoshki, A. 2005. Relasi dengan Dunia. Jakarta: Elex Media Computindo.

Bangun, Wilson. 2012. "Manajemen Sumber Daya Manusia”. Jakarta: Erlangga.

Browaeys, M. J. I., \& Price, R. 2011. Understanding cross-cultural management (2nd ed.). Harlow, England; New York: Prentice Hall

Dessler, Gary. 2011. Manajemen Sumber Daya Manusia. PT. Prenhallindo. Jakarta.

Eko, Widodo. S. 2015. Manajemen Pengembangan Sumber Daya Manusia.Yogyakarta: PUSTAKA PELAJAR. Eka, P. D. (2018). Pinisi Discretion Review The Effect of Work Discipline and Motivation on Employee. PINISI Discretion Review, 2(1), 61-68.

Fahmi, Irham. (2014). Perilaku Organisasi: Teori, Aplikasi, dan Kasus. Cetakan Kedua. Bandung: CV. Alfabeta. Anggota IKAPI.

Ghozali, Imam dan Latan, Hengky. 2015. Partial Least Square Konsep, Teknik, dan Aplikasi Menggunakan Program SmartPLS 3.0. Badan Penerbit Universitas Diponegoro. Semarang

Hasibuan, Malayu S. P. 2010. Organisasi dan Motivasi Dasar Peningkatan Produktivitas. PT Bumi Aksara. Jakarta

Hutapea, Parulian dan Nurianna Thoha, 2008, Kompetensi Plus : Teori, Desain, Kasus dan Penerapan untuk HR dan Organisasi yang Dinamis, Penerbit : Gramedia Pustaka Utama, Jakarta

Hofstede, G., Hofstede, G. J., \& Minkov, M. 2010. Cultures and organizations: software of the mind: intercultural cooperation and its importance for survival. 3rd ed. New York; London: McGraw-Hill.

Mathis, Robert L. Dan John H. Jackson. 2009. Human Resources Management (Manajemen Sumber Daya Manusia). Salemba Empat. Jakarta 
Mangkunegara, Anwar, Prabu, A. A. 2013, Manajemen Sumber Daya Manusia Perusahaan, Remaja Rosdakarya, Bandung

Robbins, Stephen P. dan Timothy A. Judge. 2012. Perilaku Organisasi (Organizational Behavior). Salemba Empat. Jakarta

Sugiyono. 2015. Metode Penelitian Pendidikan Pendekatan Kualitatif, Kuantitatif, dan R\&D. Alfabeta. Bandung

Sutrisno, Edi. 2009. Manajemen Sumber Daya Manusia Edisi pertama. Jakarta: Kencana Prenada Media Group

Sutrisno, E., 2010. Manajemen Sumber Daya Manusia. Edisi Pertama. Cetakan Pertama. Jakarta : Penerbit Kencana

Sunyoto, Danang. 2013. Manajemen Sumber Daya Manusia. Jakarta : Center for Academic Publishing Service

Rahmayanti, D., \& Afandi, I. 2016. Analisis Pengaruh Kepemimpinan, Motivasi, Lingkungan Kerja, dan Kedisplinan Terhadap Kinerja Karyawan (Studi Kasus: Operator Welding 1A, PT. XYZ Motor). Jurnal Optimasi Sistem Industri, 13(1), 556-561. doi:http://dx.doi.org/10.25077/ josi.v13.n1.p556-561.2014

Rachmawati, Ike Kusdyah. 2008. Manajemen Sumber Daya Manusia. Yogyakarta: ANDI.

Rivai, Veithzal dan Sagala, Ella Jauvani. 2011. Manajemen Sumber Daya Manusia untuk Perusahaan dari Teori ke Praktik. Jakarta: PT Raja Grafindo

Eka, P. D. (2018). Pinisi Discretion Review The Effect of Work Discipline and Motivation on Employee. PINISI Discretion Review, 2(1), 61-68.

Potu, A., Lingkungan, D., Potu Fakultas Ekonomi dan Bisnis, A., \& Manajemen Universitas Sam Ratulangi Manado, J. (2013). Kepemimpinan, Motivasi, Dan Lingkungan Kerja Pengaruhnya Terhadap Kinerja Karyawan Pada Kanwil Ditjen Kekayaan Negara Suluttenggo Dan Maluku Utara Di Manado. Jurnal EMBA, 1(4), 1208-1218.

Ramaditya, M. (2019). Examining the Impact of Corporate Social Responsibility Towards Employee Engagement (A case study: Telekom Malaysia Berhad in Kedah). 74(AICMaR 2018), 126-133. https://doi.org/10.2991/aicmar-18.2019.28

Ramaditya, M. (2019). Exploring the Impact of Perception After Rebranding and Customer Satisfaction on Corporate Image. 74(AICMaR 2018), 174-178.

Ramaditya, M., Nazzario, G., Ramaditya, M., \& Nazzario, G. (2020). Corresponding author: Reviewing editor: Keywords: 1 Departemen Manajemen, Sekolah Tinggi Ilmu Ekonomi Indonesia Jakarta. 5(2), 61-72.

Trang, Dewi Sandy. 2013. Gaya Kepemimpinan dan Budaya Organisasi Pengaruhnya terhadap Kinerja Karyawan. Jurnal EMBA

Wijono, Sutarto. 2018. Kepemimpinan dalam Perspektif Organisasi. Prenadamedia Group. Jakarta 